Filología y Lingüística 46 (1): 317-320

Abril - Setiembre 2020

ISSN: 0377-628X / EISSN: 2215-2628

Doi: https://doi.org/10.15517/rfl.v46i1.41228

URL: https://revistas.ucr.ac.cr/index.php/filyling

\title{
María V. Jordán Arroyo. Entre la vigilia y el sueño: Soñar en el Siglo de Oro. Madrid / Frankfurt: Iberoamericana / Vervuert, 2017, 326 páginas
}

En una breve "Introducción" (11-16), María V. Jordán Arroyo subraya la atracción que el "realismo" del sueño siempre ejerce con la necesidad catártica o emotiva de narrar y proponer una conexión con el orden de la biografía personal (11); así lo es porque el sueño y sus estados interpelan para que en la historia de la medicina y de otros saberes aledaños se haya decantado por investigar sus funcionamientos psíquicos y fisiológicos, así como el consumo de manuales y relatos de "oniromancia" (12) en el Siglo de Oro. Catapultado desde la Antigüedad, lo onírico se encuentra en la encrucijada entre lo sobrenatural y lo humano, para que, a partir de la Edad Moderna, la valoración de los sueños y su significado fluctúe en las antípodas: su elogio en tanto comunicación con lo divino o su desconfianza hasta llegar a la intervención demoniaca, sin perder de vista su capacidad profética o premonitaria que hace de su práctica una forma de legitimar utopías o de contrarrestar al poder. Jordán Arroyo explica, además, que su libro nace del estudio de la figura de Lucrecia de León, una "alumbrada" de su tiempo (13), para insistir en que su interés se dirige hacia el desarrollo del mundo de lo soñado, sus temáticas, una tipología narrativa de los sueños y el contexto socio-cultural.

El Capítulo I, "Entre lo divino y lo humano" (17-61), lanza la pregunta que desencadena la investigación "en torno a cuál era el origen de los sueños" (17). Su respuesta se dirige hacia la consideración tanto de procesos naturales y, por lo tanto, fisiológicos, como de las influencias sobrenaturales o externas. La filosofía, la teología y la medicina acometen esta indagación para interrogar los límites del conocimiento humano y la curiosidad humana acerca del futuro. El interés de Jordán Arroyo desemboca en "definir, limitar y evaluar el sitial del sueño como fuente de conocimiento y revelación" (18), mientras sus tensiones se enardecen ante la Contrarreforma y los debates teológicos que suscitan. Se trata no solo de encuadrar fenómenos de religiosidad popular como la práctica de visiones / sueños, sino también de controlar los matices políticos y su utilización en la propagandística contra los poderes terrenales. Por un lado, las obras médicas de los siglos XVI y XVII tratan con cautela esta problemática, al reconocer que los sueños poseen diferentes orígenes (22): una causa natural (intrínseca) que relacionaba el sueño con la vigilia y con la disposición corporal, y otra causa externa (extrínseca) que reconoce el origen sobrenatural. Esto último conducía a la tarea ingente (del confesor o del teólogo) de saber distinguir y diferenciar "la voz de dios [sic] del susurro del diablo" (22) y, de este modo, analizar las calidades morales del visionario, así como el contenido de su "sueño", es decir, si se ajustaban a la doctrina y no atentaban contra el orden y la moral. El incremento y la aparición de videntes y alumbrados en la Península obligó a desconfiar de estos fenómenos, tachándolos muchas veces de "santidad fingida" (24), mientras los teólogos y los inquisidores ejercían su celo y censura. Desde Santo Tomás de Aquino, la demonología mantenía la tesis de que Satanás podía inquirir y ocultarse en ángel de luz para manipular e influenciar a los débiles (25), por lo que las visiones y los relatos hagiográficos recurren a estos episodios de tentaciones e incursiones demoniacas: el demonio puede "susurrar" (con esa connotación 
pecadora y maligna) y, principalmente, instigar (persuadir con su poder de manipulación y moverse para volar y transportarse). Con esta finalidad, el demonio se alía de las brujas, de venenos y alucinógenos que hacen caer a los incautos (29), por lo que es necesario saber cómo reaccionar a sus embates y, lo primero, es distinguir entre fantasía y realidad por un lado (30) $\mathrm{y}$, por otro, apelar en la antesala del sueño a que la divinidad verdaderamente hablara. Toda una casuística y unas reglas de alimentación, de moderación de vida, se imponen cuando el modelo teresiano para "tender puentes" con lo inefable hace del sueño la premisa fundamental del discurso místico y del profético (33). Por su parte, también el discurso médico, desde Hipócrates y Galeno, admitió que los sueños eran un síntoma (sustitución) del estado del cuerpo, para que la teoría de los humores admitiera que los temperamentos humanos reflejaban condiciones patológicas o de salud (38): las influencias del clima y los cambios de los astros, así como las dietas y las alteraciones anímicas (39) tales como la ira, el miedo, la tristeza o la pasión amorosa, todo determinaba el tipo de sueños.

El Capítulo II, "El arte de interpretar los sueños" (63-110), gira en torno a ese "interés por descifrar el significado de las representaciones nocturnas" (63). Desde la Antigüedad, se rastrean dos métodos de investigación de los sueños, la exégesis y las guías-diccionarios. En las exégesis, la clave es el principio de sustitución que rigen las imágenes de los sueños, cuyo procedimiento es la semejanza para explicar el abordaje de los sueños (64), tal y como lo expone Artemidoro de Éfeso en su Onirocriticon, mientras los manuales, muy populares por cierto, ordenaban y clasificaban con el uso de "llaves" o sistemas, como podían ser las fases de la luna o el alfabeto, entre otros. La validación de los sueños bíblicos por un lado y, por otro, el rechazo de quienes los creían propios de la superstición religiosa, marcaron el acercamiento que la Iglesia católica otorgó a los fenómenos oníricos y de adivinación, para que los expedientes inquisitoriales acusen los casos de aprendices y maestros de oniromancia (77), que desarrollaba su "arte" en semiclandestinidad o en el ámbito doméstico. No se olvida Jordán Arroyo en plantear el valor místico y religioso de los sueños en la cultura musulmana, para que el saber onirológico se nutra de la especulación y del cruce de tradiciones occidentales y orientales dentro de la Península (79). Todo ello desemboca en la consideración también de testimonios de "religiosidad carismática" (81) o de alumbrados. La última parte de este capítulo se dedica a la descripción y el análisis del manuscrito De la interpretación de varias cosas, que se encuentra en la Universidad de Salamanca, cuya autoría se atribuye al Bakí b. Makhlad; se trata de un diccionario organizado temáticamente según la usanza árabe (99) y que se explica in extenso.

Por su parte, en el Capítulo III, "Entre la historia y los sueños" (111-147), se interroga sobre los procedimientos narrativos de los sueños y su estatuto. Jordán Arroyo comienza con el sueño de Lucrecia de León acerca del saqueo del pirata Francis Drake a La Coruña en mayo de 1589: ¿es "sueño real", "narración elaborada en vigilia y presentada bajo..." o "desvarío"? (112), se pregunta ella. A estas mismas interogantes se pueden reducir los criterios de quienes debían evaluar estas narraciones para luego catalogarlas como sueños o visiones. El teológo o el inquisidor tomaba en cuenta tanto las cualidades extrínsecas (estado de la persona, su conducta, el género, el contenido del mensaje) como las habilidades intrínsecas (carisma, dotes retóricas, mnemotécnica) del visionario. Pero Jordán Arroyo se inclina más hacia el caso de Lucrecia de León por el uso de la capacidad premonitaria de los sueños; se trata de avisorar destinos colectivos y lo hace bajo la significativa frase "Soñar la historia" (114). Interesa aquí la ingente tradición profética de tipo mesiánico para explicar el destino nacional, a causa de lo cual 
selecciona las luchas dinásticas en Portugal en el siglo XVI, así como las imágenes de asedio y de invasión (117), marcadas por la paranoia y el miedo del otro, de delirios que se propagan y retoman otras vionarias tales como la infanta Isabel o la afamada Monja de Lisboa, Sor María de la Visitación (136).

Los dos capítulos siguientes fascinan en su desarrollo. El Capítulo IV, "Sueños españoles de realidades americanas" (149-185), se dedica a delinear la figura del indiano Diego Martínez de Arce, quien se dirigió en 1699 al tribunal inquisitorial de México para autodenunciarse y entregar sus propios apuntes de sueños. En una cultura que prohíbe y censura los sueños, no es casual que Martínez se sienta perturbado no tanto por sus sueños en sí, sino por el hecho de haberlos escrito de su puño y letra. Ante esas dos posturas del origen del material de los sueños, la que sostenía la ruptura con la vida real para acceder a otra realidad alterna o la que planteaba su extensión anómala con las experiencias y los pensamientos de la vigilia (151), Jordán Arroyo propone "la interdependencia y la complementariedad de ambos mundos" (151152), toda vez que la transcripción de los sueños pasa por la mediación de las palabras, pues el sujeto debe reconstruir los retazos y los cabos sueltos ante la distancia temporal y el recuerdo: "El esfuerzo de tender puentes entre lo soñado y lo vivido en un tiempo lejano es siempre arriesgado" (155). Así, surgen las preguntas de rigor: la finalidad o el origen de una escritura impulsada por "un mandato superior" (157), frente a creencias religiosas, la curiosidad personal o el mandato del confesor (158) al que debía responder la "concienzuda introspección y examen de conciencia" (161) ante unos sueños inquietantes y siempre reprochables. La doble moral del confesor que siente curiosidad y censura se impone aquí, tal y como se exponía en los manuales de confesión desde la Contrarreforma. Para el caso americano, Jordán Arroyo estudia dos de ellos: el Confesionario mayor (1565), de Alonso de Molina, y el Confesionario escrito en lengua mexicana y castellana (1599), de fray Juan Bautista, en los que "se inculpa al soñador por los efectos y las resonancias de los sueños" (162).

Por su parte, el Capítulo V, "Juego narrativo en la cueva de Montesinos" (187-221), se dedica a la función retórica del sueño. Al retomar a Sinesio de Cirene, quien planteó la dificultad de encontrar las palabras exactas para transcribir y adentrarse en la vivencia del sueño, se plantea la inverosimilitud de la materia soñada y la necesidad de aceptar su narrativa por su forma de fabular o de contar (187). Con acierto, Jordán Arroyo aborda la estrategia de apertura del sueño en tanto marco narrativo con diferentes propósitos: satisfacer deleites carnales en la poesía erótica, mostrar lo efímero del goce terrenal, abrir una cala o ventana al mundo personal en la narración, exhibir la crítica a la realidad, mostrar la fragilidad y transitoriedad de la existencia humana, delinear proyectos de grandeza imperial, etc. (188). Aquí ella se dirige hacia la función del sueño para "enmarcar historias fantásticas" (189) y sus códigos de recepción en el debate de la credulidad o el rechazo de estos fenómenos: ¿percepción corporal (material) o percepción imaginaria (distorsionada o errada)? El episodio de la cueva de Montesinos "explora magistralmente el potencial literario o inventivo de los sueños en tanto relatos contados a posteriori" (190), cuando los personajes discuten "la veracidad de la narración quijotesca" (191), pues la narración de Don Quijote sobre lo acontecido en la cueva surge en un clima de ambigüedad, viendo las reacciones de los oyentes, cuando protestan por las incongruencias y huecos de la historia, es decir, "sobre la verdad y la naturaleza de lo relatado" (194) y, para censurarlo, el mismo Sancho Panza se apoya en "relatos épicos, historias fabulosas y pronósticos" (197), mientras Don Quijote se defiende sosteniendo la "verdad" de su experiencia onírica en su calidad de testigo fiel y cronista (198). En la yuxtaposición de ambas 
posiciones, también disparatadas, se plantea "la fabilidad de ambos discursos" (199), para que la prerrogativa de la autoridad narrativa se clarifique: "En un relato fantástico enmarcado en un sueño no existe más dios que el propio autor, él es el único que puede certificar su verdad o falsedad, ya que no hay forma de corroborar la veracidad de un sueño, ni la fidelidad del narrador en el acto de comunicación de lo soñado" (203).

El último capítulo, el VI con el título de "Fue mi maestro un sueño" (223-260), se dedica a la obra cimera de la literatura onírica, La vida es sueño. Sueños o pseudosueños, las narraciones sobre lo imaginado o soñado se cubren de un manto de ambigüiedad y de dudas, con respecto a su autenticidad en tanto experiencia real (225). La versatilidad del sueño como marco narrativo y de representación es una constante en la ilusión teatral; se propone "una escenificación del sueño o una narración gráfica del mismo" (227), para que las virtudes plásticas y teatrales dejen fuertes impresiones en los personajes. Así, una pieza como La vida es sueño con una profecía como motor de las desgracias e infortunios, además de la presencia de lo anómalo y lo maravilloso, todo ello faculta unas creencias que sirven de preámbulo a las dudas que se depositan en la mente de Segismundo y generan "la inseguridad gnoseológica y ontológica" (233), la cual lo hace dudar inmediatamente sobre su existencia. Así, de la torre al palacio se juega la experiencia dubitativa de "la vida es sueño" en la respuesta de Segismundo a Clotaldo: "pues veo estando dormido / que sueñe estando despierto" (vv. 2106-2107), cuando Calderón teatraliza el debate filosófico sobre "la incertidumbre sobre el conocimiento de las cosas" (235). El sueño se convierte en topos y en metáfora, mientras se escenifica el episodio de la vigilia a través de la farsa onírica del experimento real, que al protagonista le produce una trampa ante sus ojos, "sin poder distinguir nítidamente la realidad de la ilusión, ya fuera teatral, pictórica o, para decirlo de una manera más moderna, existencial” (258).

Jorge Chen Sham

Academia Nicaragüense de la Lengua Academia Norteamericana de la Lengua Española Universidad de Costa Rica San José, Costa Rica 